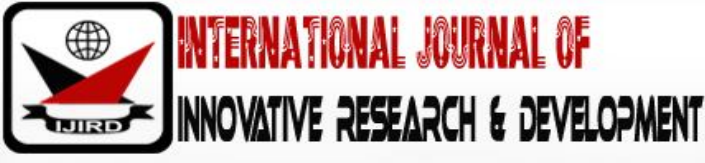

ISSN 2278 - 0211 (Online)

\section{The Effectiveness of Hydroshooter (Needle Cover Syringe) In Reducing Dental Anxiety during Local Anaesthesia}

\author{
Nor Azlina Ismail \\ Faculty of Dentistry, Universiti Sains Islam, Malaysia \\ Nusima Mohamed \\ Faculty of Dentistry, Universiti Sains Islam, Malaysia \\ Nurul Amirah Yusof \\ Faculty of Dentistry, Universiti Sains Islam, Malaysia \\ Nurul Hanisah Binti Mohd Fauzi \\ Faculty of Dentistry, Universiti Sains Islam, Malaysia \\ Nasadila Nadhira Binti Nasseri \\ Faculty of Dentistry, Universiti Sains Islam, Malaysia
}

\begin{abstract}
:
Introduction Dental fear and anxiety are frequently associated with the use of needles and syringes for local anaesthesia due to its appearance, especially in dentally anxious children. Aim \& Objectives The aim of this study is to study the effectiveness of Hydroshooter cover in reducing dental anxiety towards local anaesthesia injection. The objectives of this study are to assess the dental anxiety of patient during local anaesthetic injection based on the patient's perspective and to compare the effect of Hydroshooter cover and Conventional syringe in reducing dental anxiety during local anaesthesia injection. Methods This study involved a sample of 4 to 12 years' old healthy patients that came for dental treatment using local anaesthetic at USIM dental polyclinic. A questionnaire with Modified Child Dental Anxiety Scale (MCDAS) was designed to collect the data from the patients. The questionnaires were filled in two different appointment; each for either local anaesthetic with Hydroshooter cover or local anaesthetic with conventional method. Result. Data was available for 38 patients with a mean of age 8 years. Overall, $70 \%$ of the patients were dentally anxious towards dental appointment and about $80 \%$ of the patients reported feeling anxious about having an injection in the gum. For the conventional syringe, 88\% of the patients scored 4 and 5 for the local anaesthetic experience compared to only 15\% of patients reported anxious to receive local anaesthetic with Hydroshooter cover. Conclusion The Hydroshooter cover is effective in reducing the dental anxiety amongst patient during the local anaesthesia injection. This is corresponding with the reduction of dental anxiety score for almost $50 \%$ compared to the conventional syringe.
\end{abstract}

Keywords: Dental anxiety, needles, syringe, local anaesthesia, needles cover

\section{Introduction}

Dental anxiety is one of the most common types of anxiety amongst the population in the world, including Malaysia. According to JM Armfield et. al., a normal fear is a physiological, behavioural, and emotional response to a feared object or situation. (1) Meanwhile, the pathological anxiety is characterized by the nervousness of impending actual or imagined threat, susceptibility or doubt and may be associated with restlessness, stress, tachycardia and dyspnea unattached to a lucid identifiable reason. (2)

Studies have seen relation to the dental anxiety and its nature. 4) Dental anxiety can affect both adults and children, especially the younger children of preschool age. (5) A study has been reported that the high levels of dental anxiety strongly associated with the bad experience and traumatic dental setting, such as dental extraction and needle injection, during delivering the treatment. (6) According to Vassend et. al. and AlSarheed M., the carpule syringe contributes more in increasing the dental anxiety level, may due to the association with the placement of anaesthetic solution which is recognized as the most painful moment in dental care. (7) The placement of anaesthetic solution done by the local injection also known as local anaesthesia. Local anaesthesia is part of pharmacological behaviour management where it can cause temporary loss of sensation including pain in one part of the body produced by a topically-applied or injected agent without depressing the level of consciousness. Pain control is fundamentally vital for the successful treatment and fosters the relationship between the 
dentist and patient. Local anaesthesia helps in treatment as it reduces the anxiety and discomfort experienced by the young patient during the filling and surgical procedures. (8) This should come along with the psychological preparation of the child to give the cooperation in receiving the local anaesthesia (Milgrom et al.) (9)

For a successful dental care, the early recognition of the children dental anxiety as soon as they enter to the dental room is crucial. The patient's behaviour and perception towards dental care can be best understood by assessing the anxiety through the behavioural ratings including Modified Child Anxiety Scale (MCDAS) and Wong Baker's facial scale, as well as physiological method and psychometry method. (10) The MCDAS scoring methods are Score 1: Relaxed/ Not Worried, Score 2: Very Slightly Worried, Score 3: Fairly Worried, Score 4: Worried A Lot, Score 5: Very Worried. The interpretation of total score are <11: Not anxious; 11-14: Moderately anxious; 15-18: Highly anxious; 19-25: Extremely anxious.

\section{Methodology}

\subsection{Research Design}

This cross- sectional study carried out from April 2017 until November 2017 using Judgmental sampling. Patient who aged 4 to 12 years old attending to USIM Dental Polyclinic.

Samples/ subjects

\begin{tabular}{|c|c|}
\hline Inclusion & Exclusion \\
\hline 1) Patient who aged 4 to 12 & 1) Patient who aged $<4,>12$ \\
\hline 2) Healthy & 2) Medically compromised patient, disabled children \\
\hline $\begin{array}{c}\text { 3) Patient that had more than 1 visit of } \\
\text { treatment using local anesthesia. }\end{array}$ & $\begin{array}{c}\text { 3) Patient that had 1 visit of treatment using local } \\
\text { anesthesia. }\end{array}$ \\
\hline
\end{tabular}

Table 1

There are two versions of questionnaire; in English version and Malay version. For the English version, the questionnaire was adopted from the validated Modified Child Dental Anxiety Scale (MCDAS), established by Corah (1978). The MCDAS was adapted and validated into Malay language by Rashidah Esa et. al. (2015). A pre-test was done to 10 children before conducting this study and some amendment has been done accordingly.

Ethical approval was obtained from the institutional ethical committee Universiti Sains Islam Malaysia (USIM) before procedure. The criteria of subjects had been chosen according to the inclusion and exclusion that had been stated. 38 subjects were selected to participate in this study.

The patients had been explained that there will be 2 types of injection, named 'syringe A' and 'syringe B'. Local anaesthesia injection is done by using both conventional carpule syringe and Hydroshooter without showing the patient which syringe was A or B. The local anaesthesia solution was divided into two to do both methods. Consent is obtained from parents. In first visit, the local anaesthesia injection given using syringe A and for second visit local anaesthesia injection given using syringe B. The questionnaires were filled. All the data collected and analysed.

Three types of research tools were used which are questionnaires, Hydroshooter cover and conventional syringe.

The examples of the questionnaires are in the annexure.

\section{Results}

\subsection{Social Demographic Analysis}

Total of samples met with study criteria and participated in study: 38 samples the mean age is 8.6 year old

\begin{tabular}{|c|c|c|}
\hline Social Demographic & Subjects & Percentages \\
\hline Gender & Male & $46 \%$ \\
& Female & $54 \%$ \\
\hline Race & Malay & $88 \%$ \\
& Chinese & $12 \%$ \\
\hline
\end{tabular}

Table 2 


\subsubsection{Anxiety Level of Having An Injection in The Gum With Conventional Syringe and Hydroshooter}

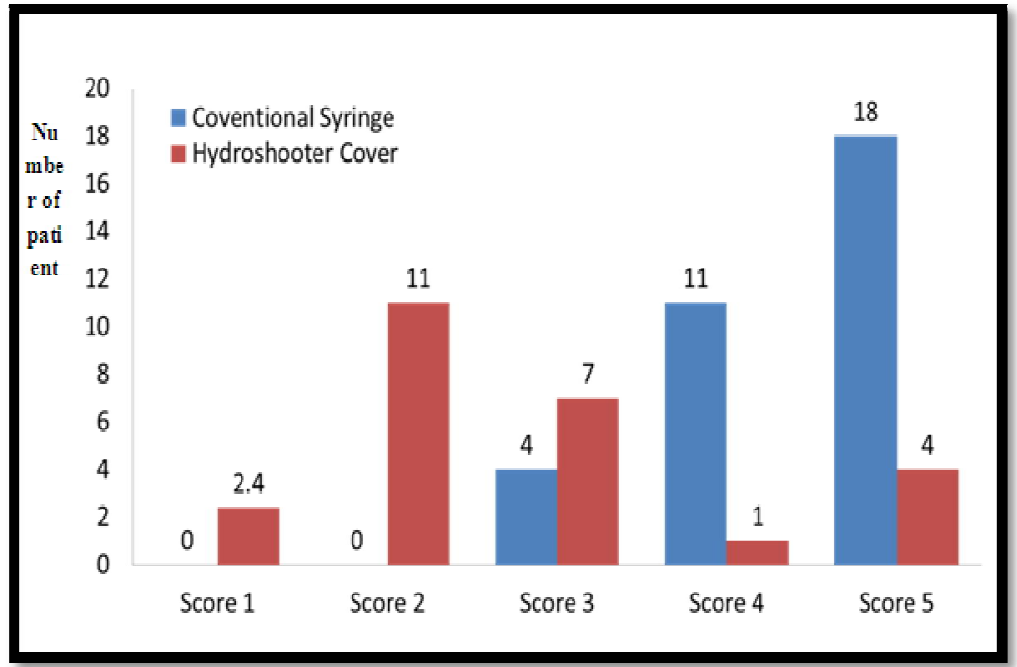

Figure 1: MCDAS Score

\subsubsection{Request of Having Injection In Future With Conventional Syringe and Hydroshooter}

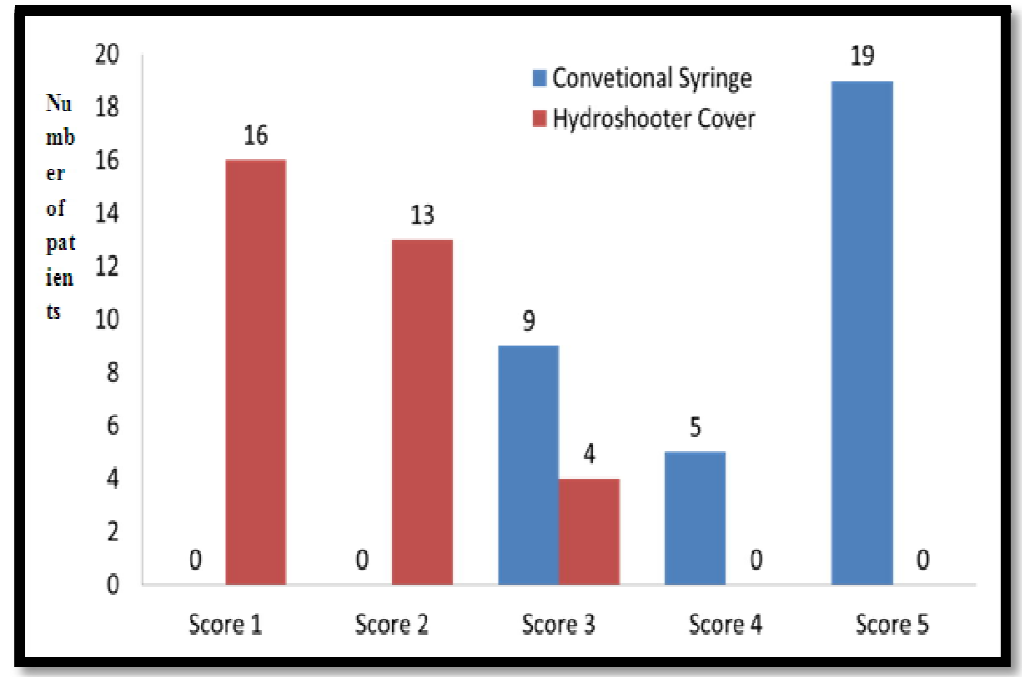

Figure 2: MCDAS Score

The graph above shows that the demand of using the Hydroshooter cover is higher compared to conventional syringe in next visit about $86 \%$.

\begin{tabular}{|c|c|c|c|}
\hline \multirow{2}{*}{$\begin{array}{c}\text { Type of } \\
\text { Syringe }\end{array}$} & \multicolumn{3}{|c|}{ Anxiety Level (\%) } \\
\cline { 2 - 4 } & $\begin{array}{c}\text { Moderately } \\
\text { Anxious }\end{array}$ & $\begin{array}{c}\text { Highly } \\
\text { Anxious }\end{array}$ & $\begin{array}{c}\text { Extremely } \\
\text { Anxious }\end{array}$ \\
\hline $\begin{array}{c}\text { Conventional } \\
\begin{array}{c}\text { Hydroshooter } \\
\text { Cover }\end{array}\end{array}$ & 12 & 27 & 61 \\
\hline
\end{tabular}

Table 3 
The study found a statistically significant difference between conventional syringe and Hydroshooter cover in reducing child's dental anxiety ( $\mathrm{p}$-value $\varangle 0.005$ ).

\section{Discussion}

The dental anxiety is a recurring feeling and it is one of the concerns in paediatric dentistry, since the feeing can influence the behaviour of the children and their pain perception (Marsac and Funk, 2008). Overall, our study showed that $70 \%$ of the patients were dentally anxious towards dental appointment. This result is corresponding with other studies which displayed more than half of the children presented from mild to moderate anxiety level (Taani et. al., 2005). Treating anxious patients might take more time due to difficult to manage during the dental care and they are often displeased with their treatment (Masoud Saatchi et. al.,2015). Thus, it is crucial to assess the level of anxiety of the child before dental treatment since it is closely related to their behaviours during dental visits (Ramos-Jorge et. al., 2006).

From our study, 88\% of the samples reported feeling anxious about having an injection in the gum. For the conventional syringe, $88 \%$ of the patients scored 4 (very worried) and 5 (extremely worried) for the local anaesthetic experience compared to only $15 \%$ of patients reported anxious to receive local anaesthetic with Hydroshooter cover. Therefore, the dental anxiety score for Hydroshooter cover has reduction more than $50 \%$ compared to the conventional syringe. Plus, even though the patient reported having anxiety during local anaesthesia using both conventional syringe and Hydroshooter cover, more than $90 \%$ of the subjects agreed that Hydroshooter cover helps to reduce their anxiety.

Non- pharmacological intervention has been suggested in order to increase acceptance of local anaesthesia (Fayle, 1997). This method may include verbal and non-verbal distraction. Distraction often works well as a behaviour management tool, especially for young children. In this study, Hydroshooter cover works as a distraction when the dentist gives local anaesthesia injection thus this cover eventually helps to reduce the dental anxiety. This is due to the fact that the appearance of the dental syringe itself can explicit a painful perception. The carpule syringe caused the highest anxiety levels, probably due to this instrument being associated with the application of anaesthesia, which is defined as the most painful moment in the treatment (Vassend et al 1995).

\section{Recommendation}

In order to assess the contribution of Hydroshooter cover in oral health at the national level, we would suggest to continuing this study in other, multiple centres and not only in Islamic Science University of Malaysia, in order to get more samples.

Besides that, we would like to include the opinion from operators that use Hydroshooter cover to assess its' simplicity and influence in managing patient's behaviour.

\section{Conclusion}

Hydroshooter cover proven to be a useful tool to decrease the dental anxiety by $50 \%$ and works as distraction during the dental treatment which is one of non-pharmacological management.

\section{Acknowledgement}

The author wishes to thank University Sains Islam Malaysia (Grant code: USIM/ RAGS/ FPG/ 36/ 50515) for financing the project. The author also would like to thank SecureFit Team from Faculty of Dentistry USIM for their contribution of invention of the Hydroshooter.

\section{References}

i. $\quad$ Queiroz, A. M., Carvalho, A. B., Censi, L. L., Cardoso, C. L., Leite-Panissi, C. R., Silva, R. A. B. D., ... \& Silva, L. A. B. D. (2015). Stress and anxiety in children after the use of computerized dental anaesthesia. Brazilian dental journal,26(3), 303307.

ii. Jimeno, F. G., Bielsa, S. Y., Fernández, C. C., Rodríguez, A. L., \& Bellido, M. M. (2011). Objective and subjective measures for assessing anxiety in paediatric dental patients. Eur J Paediatr Dent, 12, 239-44.

iii. Gustafsson, A. (2010). Dental behaviour management problems among children and adolescents-a matter of understanding? Studies on dental fear, personal characteristics and psychosocial concomitants.

iv. Skaret, E., Berg, E., Kvale, G., \& Raadal, M. (2007). Psychological characteristics of Norwegian adolescents reporting no likelihood of visiting a dentist in a situation with toothache. International Journal of Paediatric Dentistry, 17(6), 430438.

v. Venham, L. L., Gaulin-Kremer, E., Munster, E., Bengston-Audia, D., \& Cohan, J. (1980). Interval rating scales for children's dental anxiety and uncooperative behaviour. Pediatr Dent, 2(3), 195-202.

vi. Leal, A. M., Serra, K. G., Queiroz, R. C., Araújo, M. A., \& Maia Filho, E. M. (2013). Fear and/ or anxiety of children and parents associated with the dental environment. Eur J Paediatr Dent, 14(4) , 269-72. 
vii. Farhat-McHayleh, N., Harfouche, A., \& Souaid, P. (2009). Techniques for managing behaviour in pediatric dentistry: comparative study of live modelling and tell-show-do based on children's heart rates during treatment. Journal of the Canadian Dental Association, 75(4).

viii. Saxena, P., Gupta, S. K., Newaskar, V., \& Chandra, A. (2013). Advances in dental local anaesthesia techniques and devices: An update. National journal of maxillofacial surgery,4(1), 19.

ix. Potter, C. M., Kinner, D. G., Tellez, M., Ismail, A. I., \& Heimberg, R. G. (2014). Clinical implications of panic symptoms in dental phobia. Journal of anxiety disorders,28(7), 724-730.

x. $\quad$ Armfield, J. M., \& Heaton, L. J. (2013). Management of fear and anxiety in the dental clinic: a review. Australian dental journal, 58(4), 390-407.

xi. Singh, N., Agarwal, S., Bhagchandani, J., Chandra, P., \& Gaur, A. (2013). Painless anaesthesia: A new approach.J Dentofac Sci, 2, 49-55.

\section{Annexure}

\section{Ouestionnaires For Patient (Syringe A)}

\section{Name:.}

Gender:

Date Of Birth:

Race:

Date:.

Please answer the following questions. Choose the best picture to answer the questions.

1) How do you feel about going to the dentist generally?

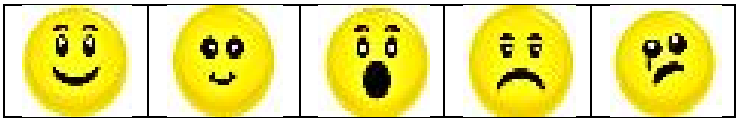

2) How do you feel when the dentist examines your teeth?

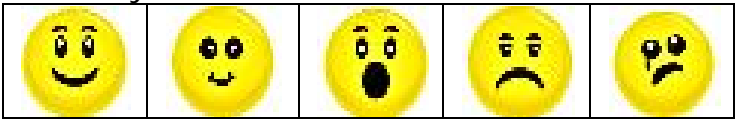

3) How do you feel about having an injection in the gum?

\begin{tabular}{|l|l|l|l|l|}
60 & 00 & 60 & $\div$ & 9 \\
\hline
\end{tabular}

4) How do you feel having injection using Syringe A performed by the dentist?

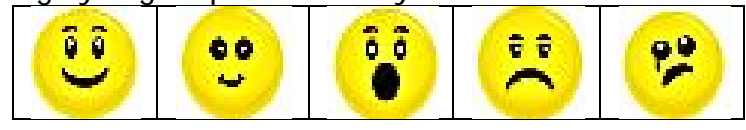

5) How do you feel about having injection again in the future?

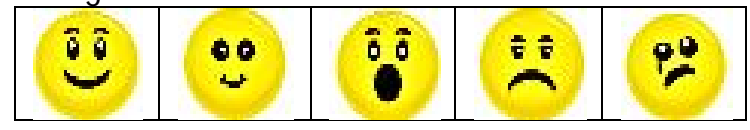

\section{Questionnaires For Patient (Syringe B)}

\section{Name:.}

Gender:

Date Of Birth:

Race:

Date:.

Please answer the following questions. Choose the best picture to answer the questions.

1) How do you feel about going to the dentist generally? 


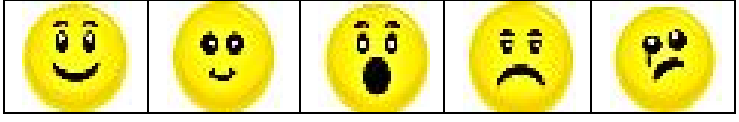

2) How do you feel when the dentist examines your teeth?

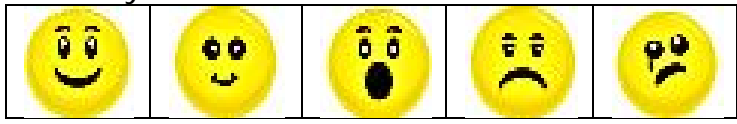

3) How do you feel about having an injection in the gum?

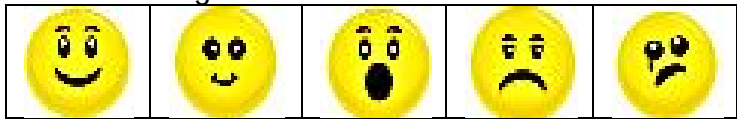

4) How do you feel having injection using Syringe B performed by the dentist?

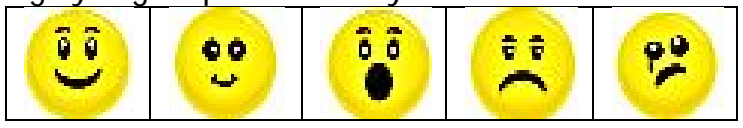

5) How do you feel about having injection again in the future?

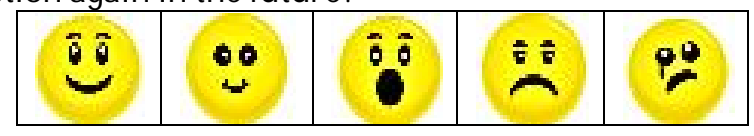

6) If applicable, which one between syringe A and syringe B, will you choose if you need any injection again in the future?

Please give your reason.

\section{'Questionairre in Malay for Syringe A}

\section{Soal Selidik Untuk Pesakit (Alat Suntikan A)}

\section{Nama:}

\section{Jantina:}

Tarikh Lahir:

Bangsa:.

Tarikh:.

Sila jawab soalan-soalan di bawah. Pilih jawapan tebaik untuk menjawab soalan-soalan berikut.

1)Apakah perasaan anda ketika hendak bertemu dengan doktor gigi secara umumnya?

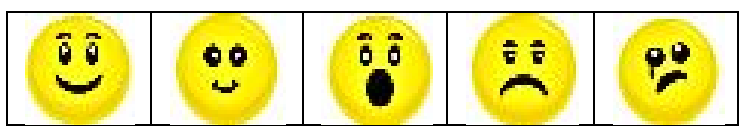

2)Apakah perasaan anda apabila doktor gigi memeriksa gigi anda?

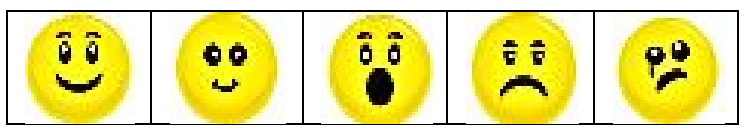

3)Apakah perasaan anda ketika disuntik di bahagian gusi?

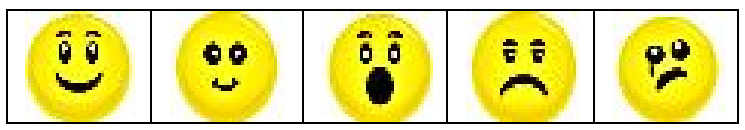

4)Apakah perasaan anda tentang suntikan menggunakan alat suntikan A yang silaksanakan oleh doktor gigi? 


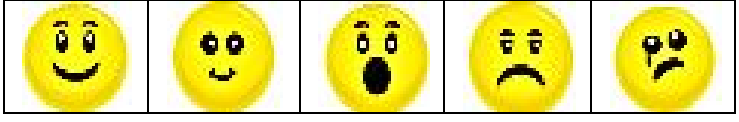

5)Apakah perasaan anda tentang suntikan semula pada masa hadapan?

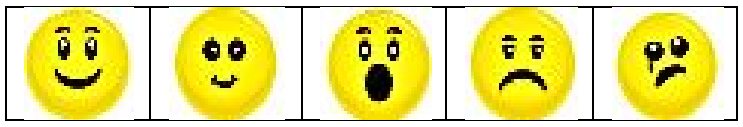

\section{Questionairre in Malay for Syringe B}

\section{Soal Selidik Untuk Pesakit (Alat Suntikan B)}

Nama:.

Jantina:

Tarikh Lahir:.

\section{Bangsa:}

\section{Tarikh:}

Sila jawab soalan-soalan di bawah. Pilih jawapan tebaik untuk menjawab soalan-soalan berikut.

1)Apakah perasaan anda ketika hendak bertemu dengan doktor gigi secara umumnya?

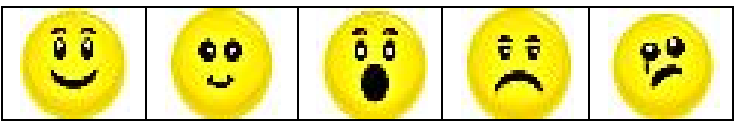

2)Apakah perasaan anda apabila doktor gigi memeriksa gigi anda?

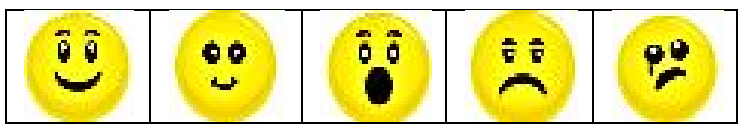

3)Apakah perasaan anda ketika dicucuk di bahagian gusi?

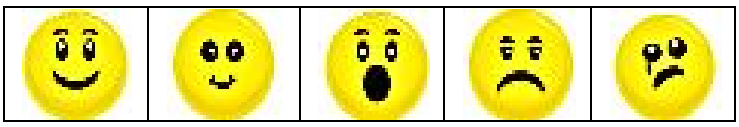

4)Apakah perasaan anda tentang suntikan menggunakan alat suntikan A yang silaksanakan oleh doktor gigi?

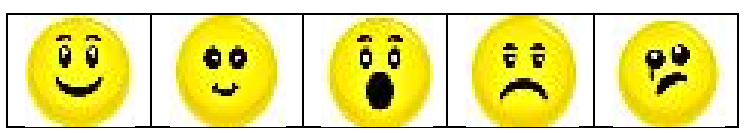

5)Apakah perasaan anda tentang suntikan semula pada masa hadapan?

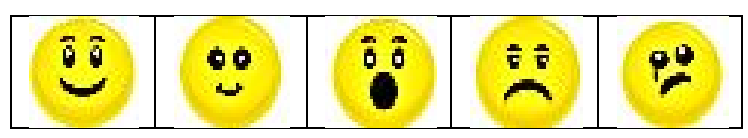

6) Sekiranya sesuai, antara alat suntikan A dan B, yang manakah yang akan anda pilih untuk suntikan lain di masa hadapan? Sila nyatakan alasan anda. 